Vol. 3, No. 2, 2021

https://doi.org/10.23939/jtbp2021.02.039

Volodymyr Gunka ${ }^{1}$, Yuriy Prysiazhnyi ${ }^{1}$, Yurii Hrynchuk ${ }^{2}$, Iurii Sidun ${ }^{3}$, Yuriy Demchuk ${ }^{1}$, Volodymyr Bidos ${ }^{3}$, Volodymyr Reutskyy ${ }^{2}$, Michael Bratychak ${ }^{1}$

\title{
INVESTIGATION OF THE PROCESS OF MODIFICATION OF PETROLEUM ROAD BITUMEN BY MALEIC ANHYDRIDE
}

\author{
${ }^{1}$ Department of Chemical Technology of Oil and Gas Processing \\ ${ }^{2}$ Department of Physical, Analytical and General Chemistry \\ ${ }^{3}$ Department of Highways and Bridges, \\ Lviv Polytechnic National University \\ siduniurii@gmail.com
}

(C) Gunka V., Prysiazhnyi Y., Hrynchuk Y., Sidun I., Demchuk Y., Bidos V., Reutskyy V., Bratychak M., 2021

The possibility of modification of oxidized petroleum bitumen 70/100 produced by JSC "Ukrtatnafta" (Kremenchuk, Ukraine) with maleic anhydride was studied. The influence of maleic anhydride amount, process duration, and temperature on the main physical and mechanical characteristics of modified bitumen was studied. The optimal amount of maleic anhydride introduction to bitumen was established. It is found that $2 \mathrm{wt} . \%$ maleic anhydride allows to increase the softening temperature of the modified bitumen (from $46{ }^{\circ} \mathrm{C}$ to $52{ }^{\circ} \mathrm{C}$ ). Adhesion to crushed stone also increases (from 2.5 points to 4.5 points) and other indicators improve. Sufficient time to modify the bitumen with maleic anhydride was 30 minutes. The optimum modification temperature for obtaining the modified bitumen with maleic anhydride is $130{ }^{\circ} \mathrm{C}$. Increasing the temperature of the modification has a negative effect on the final physical and mechanical properties of the binder.

Keywords: oxidized petroleum bitumen, maleic anhydride, modified bitumen, chemical modification, heat resistance of bitumen, adhesion to crushed stone.

\section{Introduction}

In the road industry, bitumen is needed to bind the mineral material that makes up road surfaces, as well as to improve hydrophobic properties and fill voids. However, during operation, bitumen is affected by a number of factors: temperature differences, solar radiation, oxygen from the air, increased loads caused by heavy traffic. As a result, pavements lose their integrity in advance due to the deterioration of road bitumen. The properties of any substance, including road bitumen, can be improved in two different ways - by changing the production technology or by targeting the finished product. Since the first approach requires the restructuring of the entire material production system, preference is given to the second method, which is implemented by modifying the bitumen. (Hrynchuk, 2020; Starchevskyy, 2021; Gunka, 2020; Pyshyev, 2020; Demchuk, 2020; Bratychak, 2021).

Despite the fact that in Ukraine the last few decades were dedicated to solving of the problem of the quality of road construction materials, it is still extremely relevant today. The current state of affairs with the intensive restoration of existing and construction of new roads using modern world technologies sets the tone in the development of this area of research to improve the properties of road bitumen. In particular, it is related to the program "Large Construction" - a state program aimed at large-scale development of quality infrastructure in Ukraine, which has been successfully implemented in Ukraine since 2020. 
Scientists of the Lviv Polytechnic National University alongside with scientific institutions, laboratories and other specialized institutions are actively working to find and create new quality road construction materials, as well as improve the quality of existing ones. In particular, the Department of Chemical Technology of Oil and Gas Refining is conducting experimental research in this area. Also, recently, in the framework of the project "Obtaining bitumen from petroleum residues, modified by low molecular weight organic compounds" from the National Research Fund of Ukraine, scientists of the mentioned above department co-authored with scientists from the departments of Highways and Bridges and Physical, Analytical and General Chemistry and are working on the modification of the residues and substandard road oil bitumens with formaldehyde and maleic anhydride in order to obtain bitumens of the required quality.

The results of scientific works (Herrington, 1999; Duty, 1980; Xinxing, 2016; Yu, 2015; Nadkarni, 1985; Kang, 2010; Singh, 2013; Cong, 2011; Dechong, 2016; Luo, 2011; Mohammadiroudbari, 2016; Zhang, 2010; Angyal, 2009; Naskar, 2012; Rossi, 2013) about the chemical interaction of bitumen components with maleic anhydride indicate a positive effect of this modifier on the quality characteristics of road bitumen.

Thus, the study of the process of chemical modification of road petroleum bitumen with maleic anhydride is relevant in general and, in particular, it is interesting to study the complex effect of this modifier on the qualitative characteristics of bitumen.

\section{Aim of this article}

Investigation of chemical modification of road bitumens with maleic anhydride using modern methods of analysis.

\section{Testing methods}

Modification of road bitumens with maleic anhydride was carried out in a laboratory installation, the scheme of which is shown in Fig. 1.

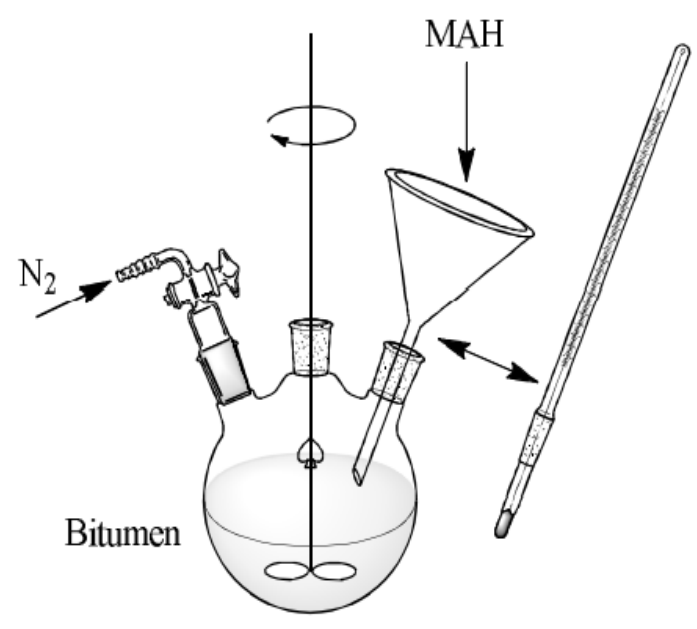

Fig. 1. Scheme of a laboratory installation for chemical modification of road bitumens with maleic anhydride

Bitumen was loaded into a round bottom three-necked flask, heated to operating temperature, a modifying agent, maleic anhydride, was added, and the initial time of the process was recorded, and modification was performed with stirring. The process was performed in nitrogen media. 
Based on the definition of quality indicators of the obtained product, it was concluded that it meets the requirements of regulatory documents in the field of bituminous road construction materials.

The modification conditions are presented in Table 1.

Table 1

Conditions for BND modification with maleic anhydride

\begin{tabular}{|c|c|}
\hline Index & Value \\
\hline Temperature, ${ }^{\circ} \mathrm{C}$ & $130-180$ \\
\hline Duration, min. & $30-180$ \\
\hline $\begin{array}{c}\text { Consumption of maleic anhydride } \\
\text { (value relative to the initial petroleum residue), \% mac. }\end{array}$ & $1-4$ \\
\hline
\end{tabular}

\section{Techniques used}

Paving bitumen BND 70/100 (oxidized bitumen) produced at JSC Ukrtatnafta (Kremenchuk, Ukraine) was used for the research. Its proprties is given in Table 2, designated as BND and maleic anhydride (MAN) in the form of white crystalline powder (used as a process modifier / chemical reagent).

Two types of stone material were used to determine the adhesion of modified oil residues to crushed stone: crushed stone from granite fr. $20-40 \mathrm{~mm}$, produced by LLC "Novograd-Volyn Stone Crushing Plant";

Table 2

Characteristics of bitumen BND

\begin{tabular}{|c|c|c|}
\hline Index & Value & Standard or Ref. \\
\hline Penetration at $25^{\circ} \mathrm{C}, \mathrm{m} \cdot 10^{-4}(0.1 \mathrm{~mm})$ & 71 & EN 1426 \\
\hline Softening temperature $(\mathrm{R} \& \mathrm{~B}),{ }^{\circ} \mathrm{C}$ & 46 & EN 1427 \\
\hline Ductility at $25^{\circ} \mathrm{C}, \mathrm{m} \cdot 10^{-2}(\mathrm{~cm})$ & $>100$ & EN 13398 \\
\hline Adhesion to crushed stone, points & 2.5 & ДСТУ 8787 \\
\hline Fraas breaking point, ${ }^{\circ} \mathrm{C}$ & -10 & EN 12593 \\
\hline Plasticity range & 56 & $\begin{array}{l}\text { is the numerical difference between } \\
\text { the softening point and Fraass breaking point }\end{array}$ \\
\hline Penetration index & -0.65 & EN 12591 \\
\hline RTFOT & & \multirow{6}{*}{ EN 12607-1 } \\
\hline Change in mass after RTFOT, wt $\%$ & 0,03 & \\
\hline Softening temperature (R\&B) after RTFOT, ${ }^{\circ} \mathrm{C}$ & 52.2 & \\
\hline Penetration at $25^{\circ} \mathrm{C}$ after RTFOT, $0.1 \mathrm{~mm}$ & 55 & \\
\hline$\Delta \mathrm{R} \& \mathrm{~B},{ }^{\circ} \mathrm{C}$ & 6.2 & \\
\hline Residual penetration, $\%$ & 77.5 & \\
\hline
\end{tabular}

\section{Results and Discussion}

We studied the influence of the main factors (amount of modifier, time and temperature) on the qualitative properties of modified bitumen with maleic anhydride. The effect of the amount of maleic anhydride on the physical and mechanical properties of the modified bitumen is shown in Table 3. 
Influence of MAH amount on physical and mechanical characteristics of modified bitumen*

\begin{tabular}{|c|c|c|c|}
\hline MAH amount, wt \% & $\begin{array}{c}\text { Softening temperature } \\
(\mathrm{R} \& \mathrm{~B}),{ }^{\circ} \mathrm{C}\end{array}$ & $\begin{array}{c}\text { Penetration at } 25^{\circ} \mathrm{C}, 0.1 \\
\mathrm{~mm}\end{array}$ & $\begin{array}{c}\text { Adhesion to crushed } \\
\text { stone, points }\end{array}$ \\
\hline Without MAH & 46 & 71 & 2.5 \\
\hline 1,0 & 49 & 44 & 3.5 \\
\hline 2,0 & 52 & 34 & 4,5 \\
\hline 3,0 & 52 & 30 & 4.0 \\
\hline 4,0 & 66 & 22 & 4.5 \\
\hline
\end{tabular}

* Temperature of process is $150^{\circ} \mathrm{C}$; duration - $60 \mathrm{~min}$.

The introduction of MAH, up to $2 \mathrm{wt.} \%$, increases the softening temperature of the modified bitumen (up to $52^{\circ} \mathrm{C}$ ). A further increase in the MAH content does not change the value of this indicator. A similar relationship is observed with other characteristics. The value of such an important indicator as adhesion to crushed stone aggregate increases from 2.5 to 4.5 points. Thus, the optimal amount of maleic anhydride for the modification of oxidized bitumen is 2 wt. \%, in addition, the modified MAH bitumen does not require expensive adhesives.

The effect of modification time on the physical and mechanical properties of the modified bitumen is shown in Table 4.

Table 4

\section{Influence of process duration on physical and mechanical characteristics of modified bitumen*}

\begin{tabular}{|c|c|c|c|}
\hline Process duration, min & $\begin{array}{c}\text { Softening temperature } \\
(\mathrm{R} \& \mathrm{~B}),{ }^{\circ} \mathrm{C}\end{array}$ & $\begin{array}{c}\text { Penetration at } 25^{\circ} \mathrm{C}, \\
0.1 \mathrm{~mm}\end{array}$ & $\begin{array}{c}\text { Adhesion to crushed } \\
\text { stone, points }\end{array}$ \\
\hline 15 & 50 & 71 & 2.5 \\
\hline 30 & 53 & 35 & 4.0 \\
\hline 60 & 52 & 34 & 4.5 \\
\hline 120 & 50 & 37 & 4.0 \\
\hline 180 & 51 & 35 & 4.0 \\
\hline
\end{tabular}

* Temperature of process is $150{ }^{\circ} \mathrm{C}$; amount of $M A H-2 w t . \%$.

The results show that 30 minutes is enough to modify the bitumen with maleic anhydride, because during this time the highest value of the softening temperature is reached. The effect of temperature on the modification of bitumen with maleic anhydride is presented in Table 5.

Table 5

Influence of temperature on physical and mechanical characteristics of modified bitumen*

\begin{tabular}{|c|c|c|c|}
\hline Temperature, ${ }^{\circ} \mathrm{C}$ & $\begin{array}{c}\text { Softening temperature } \\
(\mathrm{R} \& \mathrm{~B}),{ }^{\circ} \mathrm{C}\end{array}$ & $\begin{array}{c}\text { Penetration at } 25^{\circ} \mathrm{C}, \\
0.1 \mathrm{~mm}\end{array}$ & $\begin{array}{c}\text { Adhesion to crushed } \\
\text { stone, points }\end{array}$ \\
\hline 130 & 60 & 27 & 4.0 \\
\hline 150 & 53 & 35 & 4.0 \\
\hline 170 & 52 & 32 & 4.0 \\
\hline
\end{tabular}

* Amount of MAH - 2 wt.\%, duration of modification is $30 \mathrm{~min}$. 
As can be seen from the results at a modification temperature of $130{ }^{\circ} \mathrm{C}$, there is a significant increase in the softening temperature $-60{ }^{\circ} \mathrm{C}$. And at higher modification temperatures of $150-170{ }^{\circ} \mathrm{C}$, this figure is much lower than 53 and $52{ }^{\circ} \mathrm{C}$, respectively, which may be due to different ways of chemical interaction of maleic anhydride with the components of oxidized bitumen at different temperatures.

For comparison, a study of the heat resistance of the modified bitumen at a modification temperature of $130{ }^{\circ} \mathrm{C}$ (Sample 1) and a modification temperature of $170{ }^{\circ} \mathrm{C}$ (Sample 2) was performed. The samples were heated in a thermal chamber using the method of resistance to hardening under the influence of heat and air (RTFOT) (Table 6).

Table 6

Physico-mechanical parameters of bitumen after RTFOT

\begin{tabular}{|l|c|c|c|c|c|c|}
\hline \multirow{2}{*}{ Index } & \multicolumn{3}{c|}{ Before RTFOT } & \multicolumn{3}{c|}{ After RTFOT } \\
\cline { 2 - 8 } & BND & Sample 1 & Sample 2 & BND & Sample 1 & Sample 2 \\
\hline Change in mass after RTFOT, wt \% & - & - & - & 0.03 & 0.23 & 0.55 \\
\hline Softening temperature (R\&B) after RTFOT, ${ }^{\circ} \mathrm{C}$ & 46 & 60 & 52 & 52.2 & 52.4 & 55.2 \\
\hline Penetration at $25^{\circ} \mathrm{C}$ after RTFOT, 0.1mm & 71 & 27 & 32 & 55 & 38 & 35 \\
\hline AR\&B, ${ }^{\circ} \mathrm{C}$ & - & - & - & 6.2 & -7.6 & 3.2 \\
\hline Residual penetration, \% & - & - & - & 77.5 & 140.7 & 109.4 \\
\hline
\end{tabular}

After the RTFOT heating of Sample 1, which was obtained by modification with maleic anhydride at a temperature of $130{ }^{\circ} \mathrm{C}$, there is a decrease in its softening temperature by 7.6 degrees, while the softening temperature of BND and Sample 2 increases by 6.2 and 3,2 degrees respectively. Obviously, the structure of Sample 1 is destroyed by heating with a significant decrease in heat resistance. Therefore, to obtain a modified bitumen with such a high temperature, the softening of the modification with maleic anhydride should be carried out at a relatively low temperature of $130{ }^{\circ} \mathrm{C}$. It is important to adhere to this temperature regime also for preparation of asphalt concrete mixes.

\section{Conclusions}

The process of modification of road bitumen with maleic anhydride was studied. The following conclusions can be drawn from research:

- $\quad 2$ wt. $\%$ addition of maleic anhydride allows to increase the softening temperature of the modified bitumen BND $70 / 100$ to $60{ }^{\circ} \mathrm{C}$ and adhesion to crushed granite from 2.5 to 4.5 points;

- the optimal temperature of the modification process with maleic anhydride $130{ }^{\circ} \mathrm{C}$ and a time of 30 minutes;

- modified bitumen with much lower heat resistance will be obtained at higher temperatures of $150-170{ }^{\circ} \mathrm{C}$;

- in general, the addition of maleic anhydride to bitumen makes it possible to improve its adhesive and heat-resistant properties.

\section{Acknowledgements}

This work was supported by the National Research Foundation of Ukraine (Grant No. 2020.02/0038).

\section{References}

Hrynchuk Y., Sidun I., Gunka V., Reutskyy V., Koval I., Matcipura P., Mosiuk M. (2020) Possibility Improvement Technology of Modification Road Bitumen by the Green Epoxy Rapeseed Oil on the Basis of Renewable Raw Material. Petroleum \& Coal,62 (4), 1566-1571. https://www.vurup.sk/wp-content/uploads/2020/ 12/PC-X_-Gunka_105.pdf 
Starchevskyy V., Hrynchuk Y., Matcipura P., Reutskyy V. (2021) Influence of initiators on the adhesion properties of bitumen modified by natural origin epoxide. Chemistry \& Chemical Technology, 15(1), 142-147. https://doi.org/10.23939/chcht15.01.142

Gunka, V., Demchuk, Y., Sidun, I., Nyakuma, B.B., Pyshyev, S. (2020) Application of phenol-cresolformaldehyde resin as an adhesion promoter for bitumen and asphalt concrete. Road Materials and Pavement Design. https://doi.org/10.1080/14680629.2020.1808518

Pyshyev, S., Prysiazhnyi, Y., Sidun, I., Borbeyiyong, G.I., Korsh, D. (2020) Obtaining of resins based on model mixtures with indene, coumarone and styrene and their usage as bitumen modifiers. Petroleum and Coal, 62(2), 341-346 https://www.vurup.sk/wp-content/uploads/2018/11/PC_x_2018_Gunka-73.pdf

Demchuk, Y., Gunka, V., Pyshyev, S., Kucinska-Lipka, J., Bratychak, M. (2020) Slurry surfacing mixes on the basis of bitumen modified with phenol-cresol-formaldehyde resin. Chemistry and Chemical Technology, 14(2), 251-256 https://doi.org/10.23939/chcht14.02.251

Bratychak M., Gunka V., Prysiazhnyi Y., Hrynchuk Y., Sidun I., Demchuk Y., Shyshchak O. (2021) Production of bitumen modified with low-molecular organic compounds from petroleum residues. 1. effect of solvent nature on the properties of petroleum residues modified with folmaldehyde. Chemistry and Chemical Technology, 15(2), 274-283. https://doi.org/10.23939/chcht15.02.274

Herrington, P. R.; Wu, Y.; Forbes, M. C. (1999) Rheological modification of bitumen with maleic anhydride and dicarboxylic acids. Fuel, 78(1), 101-110. https://doi.org/10.1016/S0016-2361(98)00120-3

Duty, R. C.; Liu, H. F. (1980) Study of the reaction of maleic anhydride with Illinois bituminous coal. Fuel, 59(8), 546-550. https://doi.org/10.1016/0016-2361(80)90230-6

Xinxing Zhou, Shaopeng Wu, Gang Liu, Pan Pan. (2016) Molecular simulations and experimental evaluation on the curing of epoxy bitumen. Materials and Structures, 49(1-2), 241-247. https://link.springer.com/ article/10.1617/s11527-014-0491-4

Yu, L., (2015) Application of Epoxy Asphalt to Adhesive Layer for Deck of Long-Span Steel Bridge, Highway, 3, 56-59. https://doi.org/10.1155/2021/3454029

Nadkarni V., Shenoy A., Mathew J. (1985) Thermomechanical behavior of modified asphalts. Industrial \& Engineering Chemistry Product Research and Development, 24 (3), 478-484 https://doi.org/10.1021/i300019a029

Kang Yang, Fei Wang, Zhiming Chen (2010) Reaction of asphalt and maleic anhydride: Kinetics and mechanism. Chemical Engineering Journal, 164(1), 230-237. https://doi.org/10.1016/j.cej.2010.08.020

Singh, B., Kumar, L., Gupta, M., \& Chauhan, G. S. (2013) Polymer $\square$ modified bitumen of recycled LDPE and maleated bitumen. Journal of applied polymer science, 127(1), 67-78. https://doi.org/10.1002/app.36810

Cong, P., Chen, S., \& Chen, H. (2011). Preparation and properties of bitumen modified with the maleic anhydride grafted styrene $\square$ butadiene $\square$ styrene triblock copolymer. Polymer Engineering \& Science, 51(7), 12731279. https://doi.org/10.1002/pen.21934

Dechong Ma, Duijia Zhao, Jingzhe Zhao, Sujun Du, Jinyu Pang, Wei Wang, Changxin Fan (2016) Functionalization of reclaimed polyethylene with maleic anhydride and its application in improving the high temperature stability of asphalt mixtures. Construction and Building Materials, 113, (596-602), https://doi.org/10.1016/j.conbuildmat.2016.03.096

Luo, W. Q., \& Chen, J. C. (2011). Preparation and properties of bitumen modified by EVA graft copolymer. Construction and Building Materials, 25(4), 1830-1835. https://doi.org/10.1016/j.conbuildmat. 2010.11.079

Mohammadiroudbari, M., Tavakoli, A., Aghjeh, M. K. R., \& Rahi, M. (2016). Effect of nanoclay on the morphology of polyethylene modified bitumen. Construction and building materials, 116, 245-251. https://doi.org/ 10.1016/j.conbuildmat.2016.04.098

Zhang, S. L., Zhang, Z. X., Xin, Z. X., Pal, K., \& Kim, J. K. (2010). Prediction of mechanical properties of polypropylene/waste ground rubber tire powder treated by bitumen composites via uniform design and artificial neural networks. Materials \& Design, 31(4), 1900-1905 https://doi.org/: 10.1016/j.matdes.2009.10.057

Naskar, M., Chaki, T. K., \& Reddy, K. S. (2012). A novel approach to recycle the waste plastics by bitumen modification for paving application. Advanced Materials Research, 356, 1763-1768). https://doi.org/10.4028/www.scientific.net/AMR.356-360.1763

Angyal, A., Miskolczi, N., Bartha, L., \& Gergo, P. (2009). Synthesis and evaluation of modified polyethylene wax applied as dispersant in rubber bitumen composites. Hungarian Journal of Industry and Chemistry, 37(1), 21-25 https://doi.org/10.1515/217 
Rossi, D., Filippi, S., Merusi, F., Giuliani, F., \& Polacco, G. (2013). Internal structure of bitumen/ polymer/wax ternary mixtures for warm mix asphalts. Journal of Applied Polymer Science, 129(6), 3341-3354. https://doi.org/10.1002/app.39057

В. М. Гунька ${ }^{1}$, Ю. В. Присяжний ${ }^{1}$, Ю. М. Гринчук ${ }^{2}$ Ю. В. Сідун ${ }^{3}$ Ю. Я. Демчук ${ }^{1}$, В. М. Бідось ${ }^{3}$, В. Реутський ${ }^{2}$ М. М. Братичак ${ }^{1}$

Національний університет “Львівська політехніка”, ${ }^{1}$ кафедра хімічної технології переробки нафти та газу,

2 кафедра фізичної, аналітичної та загальної хімії,

${ }^{3}$ кафедра автомобільних доріг та мостів

\section{ДОСЛІДЖЕННЯ ПРОЦЕСУ МОДИФІКУВАННЯ НАФТОВОГО ДОРОЖНЬОГО БІТУМУ МАЛЕЇНОВИМ АНГІДРИДОМ}

(C) Гунька В. М., Присяжний Ю. В., Гринчук Ю. М., Сідун Ю. В.,

Демчук Ю. Я., Бідось В. М., Реутський В. В., Братичак М. М., 2021

Вивчено можливість модифікації окисненого нафтового бітуму 70/100 виробництва ВАТ “Укртатнафта" (м. Кременчук, Україна) малеїновим ангідридом. Детально досліджено фізико-механічні властивості бітуму 70/100 виробництва ВАТ “Укртатнафта”. Наведено технологічні особливості та приладдя для модифікації бітуму малеїновим ангідридом у лабораторних умовах. Досліджено вплив кількості малеїнового ангідриду, тривалості процесу та температури на основні фізикомеханічні характеристики модифікованого бітуму. Встановлено оптимальну кількість введення малеїнового ангідриду до бітуму. Встановлено, що 2 мас. \% малеїнового ангідриду дає змогу збільшити температуру розм' якшеності модифікованого бітуму (із $46{ }^{\circ} \mathrm{C}$ до $52{ }^{\circ} \mathrm{C}$ ) також зростає зчеплюваність із щебенем (з 2,5 бала до 4,5 балів) та змінюється глибина проникнення голки (пенетрація). Достатній час для модифікації бітуму за допомогою малеїнового ангідриду становив 30 хв. Визначили термостійкість бітуму модифікованого малеїновим ангідритом за температури модифікації $130{ }^{\circ} \mathrm{C}$ та $170{ }^{\circ} \mathrm{C}$ та вихідного бітуму 70/100 виробництва ВАТ “Укртатнафта" за методом визначення опору до твердіння під впливом теплоти та повітря (RTFOT). Встановлено, що структура зразка бітуму 3 малеїновим ангідридом, який був модифікований за температури $130{ }^{\circ} \mathrm{C}$, руйнується за нагрівання зі значним зниженням теплостійкості. Для отримання модифікованого бітуму малеїновим ангідридом оптимальною температурою модифікації $є 130{ }^{\circ} \mathrm{C}$. Збільшення температури модифікації негативно впливає на кінцеві фізико-механічні показники в’язкого. Висунуто припущення, що за додавання малеїнового ангідриду до вихідного бітуму 70/100 виробництва ВАТ “Укртатнафта" відбувається не фізична модифікація бітуму, а хімічна.

Ключові слова: окиснений нафтовий бітум, малеїновий ангідрид, модифікований бітум, хімічна модифікація, термостійкість бітуму, зчеплюваність із щебенем. 